\title{
PENGARUH LAMA PERENDAMAN DALAM GEL LIDAH BUAYA (Aloe vera TERHADAP KUALITAS TELUR AYAM RAS
}

\author{
Asrul Lamarang, A. Yelnetty ${ }^{*}$, L.Ch.M. Karisoh, N.N. Lontaan \\ Fakultas Peternakan Universitas Sam Ratulangi Manado, 95115
}

\begin{abstract}
ABSTRAK
Penelitian dilakukan untuk mengetahui pengaruh lama perendaman telur ayam ras dalam gel lidah buaya (Aloe vera) terhadap kualitas telur ayam ras selama penyimpanan. Bahan yang digunakan dalam penelitian ini adalah telur ayam ras yang masih segar berumur satu hari dengan berat $55-60$ gram. Aloe vera diperoleh dari pusat tanaman hias Kelurahan Bahu. Alat-alat yang digunakan dalam penelitian adalah: pisau, timbangan, blender, wadah, diameter caliper, egg candlling, cawan petri. Metode yang digunakan adalah metode rancangan acak lengkap (RAL) dengan pola faktorial 5 x 5 dengan ulangan, Faktor A adalah lama perendaman dan faktor $\mathrm{B}$ adalah lama penyimpanan. Variabel yang diamati adalah berat telur, indeks putih telur, indeks kuning telur, dan haugh unit. Data yang diperoleh dianalisis menggunakan ANOVA. Hasil penelitian menunjukkan bahwa tidak terdapat perbedaan yang nyata $(\mathrm{P}>0.05)$ terhadap berat telur. Namun terdapat perbedaan yang nyata $(\mathrm{P}<0.05)$ terhadap indeks putih telur, indeks kuning telur, dan haugh unit. Perendaman telur ayam ras dalam gel lidah buaya dapat memperpanjang lama penyimpanan hingga 30 hari.
\end{abstract}

Kata Kunci: Telur, Aloe vera, Penyimpanan, Kualitas Fisik

*Korespondensi(corresponding Author)

Email:yelnetty_makmur@yahoo.com
ABSTRAK

THE EFFECT OF IMMERSION IN GEL OF ALOE VERA ON THE QUALITY OF CHICKEN EGGS DURING STORAGE. The study was conducted to determine the duration effect of immersion of chicken eggs in aloe vera extract (Aloe Vera) on the quality of broiler eggs during storage. The material used in this study was freshly bred eggs at first day at weight of $55-60$ grams. Aloe vera was obtained from the center of the ornamental plant of Bahu Village. The tools used in the study were including knives, scales, blenders, containers, diameter caliper, egg candlling, petri dishes. The method used was a completely randomized design (CRD) method with factorial pattern of a 5 x 5 with 3 replications. Factor A was the immersion time and factor B was the storage time. The observed variables were egg weight, egg white index, egg yolk index, and haugh unit. The data obtained were analyzed using ANOVA. The results of this study indicated that there was no significant difference $(\mathrm{P}>0.05)$ on Egg Weight, however, there were significant differences $(\mathrm{P}<0.05)$ on the egg white Index, Egg Yolk Index and Haugh Unit. Soaking eggs in aloe vera gel could extend the storage time up to 30 days.

Keywords: Eggs, Aloe vera, Storage, Physical Quality 


\section{PENDAHULUAN}

Telur merupakan salah satu bahan pangan yang paling praktis digunakan, kaya akan protein, karbohidrat, vitamin dan mineral dan sangat mudah dicerna. Telur bersifat serba guna karena dapat dimanfaatkan untuk berbagai keperluan dan muda diperoleh dengan harga yang relatif murah, sehingga dapat dijangkau dengan daya beli masyarakat pada umumnya.

Sebagai bahan makanan, telur merupakan bahan yang mudah mengalami kerusakan baik secara fisik, kimiawi maupun kerusakan akibat kontaminasi mikroorganisme yang masuk melalui poripori kulit telur. Kerusakan dapat menyebabkan terjadinya penurunan kualitas telur, antara lain turunnya berat telur akibat menguapnya air dan karbondioksida, terjadinya pembesaran kantung udara, terjadi perombakan kimiawi isi telur.kerusakan ini dapat dilihat dengan cara candling terlihat adanya tanda-tanda noda didalam isi telur. Jika telur dibiarkan dalam udara terbuka (suhu ruang) telur hanya tahan 10-14 hari, Setelah lewat dari waktu tersebut telur mengalami perubahan-perubahan kearah kerusakan. Semakin lama waktu penyimpanan akan semakin besar terjadinya penguapan cairan dan gas dalam telur sehingga akan menyebabkan rongga udara makin besar yang menyebabkan putih telur kental menjadi encer (Sudaryani, 2003)

Salah satu cara yang dapat digunakan untuk mencegah terjadinya penurunan kualitas telur yaitu dengan melapisi pori-pori kulit telur sehingga dapat dicegah masuknya mikroorganisme ke dalam isi telur sehingga kualitasnya dapat dipertahankan. Salah satu bahan pelapis yang dapat digunakan guna melapisi telur adalah lidah buaya (aloe vera).

Lidah buaya (aloe vera) merupakan salah satu bahan pelapis alami yang aman untuk digunakan. Lidah buaya (Aloe vera) mempunyai lendir yang dapat digunakan untuk menutupi pori kerabang telur dan diketahui memiliki 75 senyawa antara lain saponin, tannin, flavonoid, polifenol, berbagai vitamin, enzim, antrakuinon, dan 20 jenis asam amino. Kandungan zat yang ada pada lidah buaya (Aloe vera) mempunyai khasiat anti bakteri dan anti virus (Jatnika dan Saptoningsih, 2009). Saponin bersifat anti mikroba mampu menutup kerabang telur dari penguapan, sehingga dapat mencegah penguapan pada telur (Surjushe et al., 2008). Selain kandungan senyawa yang berfungsi membunuh bakteri, sifat dari gel yang dimiliki lidah buaya dapat sebagai coating atau pelapis alami. Penggunaan gel lidah buaya telah 
diaplikasikan di industri pangan sebagai ingridien pangan fungsional, dan salah satunya dengan menjadikan gel lidah buaya sebagai bahan untuk membentuk edible coating alami dan dapat menahan laju respirasi (Valverde et al., 2005).

Berdasarkan uraian diatas, maka dilakukan penelitian penggunaan lidah buaya sebagai pengawet pada telur dengan tujuan mengetahui pengaruh lama perendaman dan penyimpanan telur ayam ras dalam gel lidah buaya (Aloe vera) terhadap kualitas telur.

\section{MATERI DAN METODE PENELITIAN}

\section{Materi Penelitian}

Bahan yang akan digunakan dalam penelitian ini adalah telur ayam ras segar berumur satu hari dengan berat $55-60$ gram sebanyak 75 butir. Lidah buaya diperoleh dari tanaman hias penduduk kelurahan Bahu. Alat-alat yang digunakan dalam penelitian adalah: pisau, timbangan, blender, wadah, diameter Caliper, egg candlling, cawan petri.

\section{Prosedur Penelitian}

1. Persiapan telur ayam ras segar yang baru ditelurkan dari peternakan ayam dan daun lidah buaya

2. Pembuatan sediaan gel dengan cara mengambil daging lidah buaya, kemudian diblender sampai halus. Bagian lidah buaya yang digunakan adalah bagian pangkal dari lidah buaya yang telah dibersihkan dan dihilangkan kulitnya. Pengambilan daging lidah buaya dilakukan dengan cara bagian pangkal lidah buaya dipotong menggunakan pisau. Kemudian lendir dikeruk dengan sendok sebanyak 50 helai daun Aloe vera yang digunakan untuk mencapai volume yang dibutuhkan untuk pencelupan telur.

3. Telur dibersihkan dengan air hangat dari kotoran yang menempel pada kulit telur.

4. Persiapan wadah/tempat perendaman telur yang telah berisi gel sebanyak 4 buah yang diberi label sesuai perlakuan, dimana pada masingmasing terdapat 3 butir telur.

5. Dilakukan pengacakan untuk menentukan telur yang akan diberikan perlakuan pada Faktor A (lama perendaman) selama $0,10,20,30$ dan 40 menit dalam gel dan Faktor B (lama penyimpanan selama 0, 10, 20, 30 dan 40 hari

6. Setelah itu telur direndam dalam gel sampai telur terendam seluruhya sesuai pengacakakan yang dilakukan.

7. Setelah perendaman selesai pada masing-masing unit perlakuan, telur diletakkan pada tempat penyimpanan 
telur sesuai perlakuan yaitu selama $(0$, 10, 20, 30, dan 40 hari),

\section{Metode Penelitian}

Metode yang digunakan dalam penelitian ini adalah metode eksperimen rancangan acak lengkap (RAL) dengan pola faktorial 5 x 5 dengan 3 ulangan, dimana perlakuan tersebut adalah:

Faktor A adalah lama perendaman telur ayam ras dalam gel lidah buaya dan Faktor B lama penyimpanan yang terdiri dari 5 taraf ;

$\mathrm{A}_{0}$ Kontrol tanpa perendaman

$\mathrm{A}_{1}$ Lama perendaman 10 menit

$\mathrm{A}_{2}$ Lama perendaman 20 menit

$\mathrm{A}_{3}$ Lama perendaman 30 menit

$\mathrm{A}_{4}$ Lama perendaman 40 menit

Faktor B adalah lama penyimpanan pada suhu ruang yang terdiri dari 5 taraf:

$\mathrm{B}_{0}$ Kontrol tanpa penyimpanan

$\mathrm{B}_{1}$ Penyimpanan selama 10 hari

$\mathrm{B}_{2}$ Penyimpanan selama 20 hari

$\mathrm{B}_{3}$ Penyimpanan selama 30 hari

$\mathrm{B}_{4}$ Penyimpanan selama 40 hari

Model Matematika yang digunakan menurut Steel dan Torrie (1991) adalah sebagai berikut:

$$
\boldsymbol{Y}_{i j}=\boldsymbol{u}+\boldsymbol{A}_{i}+\boldsymbol{B}_{j}+\boldsymbol{A B}_{i j}+\boldsymbol{K}_{k}+\sum_{i j k}
$$

Dimana:

$\mathrm{Y}_{\mathrm{ij}}: \quad$ nilai pengamatan $\mathrm{u}$ : nilai tengah umum

$\mathrm{A}_{\mathrm{i}}$ : $\quad$ Pengaruh taraf ke-i faktor $\mathrm{A}$

$B_{j}$ : Pengaruh taraf ke-j faktor B

$A B_{i j}$ : Pengaruh interaksi antara taraf ke-i faktor A dengan taraf ke-j faktor B

$\sum_{\mathrm{ijk}}$ : Pengaruh sisa

Apabila terdapat perbedaan rataan akan dilanjtkan dengan uji Duncan's Multiple Range Test (DMRT).

\section{Variabel yang Diamati}

Adapun variabel yang akan diukur adalah berat telur, indeks putih Telur, indeks kuning telur dan haugh unit.

Berat Telur. Penurunan berat telur di hitung dengan cara menimbang berat awal telur (gram), dikurangi dengan berat akhir telur (gram) setelah disimpan, dibagi dengan berat awal telur (gram), dan kemudian dikali 100\% (Muchtadi, 2009).

Dihitung menggunakan rumus:

$$
\frac{\text { Berat Awal (gram) - Berat Akhir (gram) }}{\text { Berat Awal (gram) }} \times 100 \%
$$

Perhitungan indeks putih telur dan kuning telur. Pengukuran dilakukan dengan metode pemecahan. Telur dipecahkan di atas cawan petri dan dilakukan pengamatan keadaan putih telur dan keadaan kuning telur sebagai berikut: 
1. Pemeriksaan putih telur dilakukan terhadap kebersihan dan kekentalannya.

2. Pemeriksaan kuning telur dilakukan terhadap bentuk posisi kuning telur, penampakan batas dan kebersihan kuning telur.

3. Penghitungan indeks putih telur

Penghitungan indeks putih telur dilakukan dengan mengukur tinggi albumin kental (thick albumin) menggunakan pengaris kecil dan diameter albumin kental menggunakan jangka sorong. Indeks putih telur dihitung dengan rumus menurut SNI 3926:2008 sebagai berikut :Indeks albumin =

$\frac{\text { Tinggi Abumin (mm) }}{\text { Diameter Abumin (mm) }} \times 100 \%$

4. Penghitungan indeks kuning telur

Penghitungan indeks kuning telur ditentukan dengan mengukur tinggi dan diameter kuning telur dengan jangka sorong. Indeks kuning telur (yolk index) dihitung menggunakan rumus menurut SNI 3926:2008 sebagai berikut :

Indeks kuning telur $=$
$\frac{\text { Tinggi Yolk (mm) }}{\text { Diameter Yolk (mm) }} \times 100 \%$

Haugh Unit. Haugh Unit menurut Sudaryani (2000) dengan rumus:

$\mathrm{HU}=100 \log \left(\mathrm{H}+7,57-1,7 \times \mathrm{W}^{0,37}+7,6\right)$

Keterangan:

$\mathrm{HU}=$ haugh unit

$$
\begin{aligned}
& \mathrm{H}=\text { tinggi albumin telur } \\
& \mathrm{W}=\text { bobot telur (gram) }
\end{aligned}
$$

\section{HASIL DAN PEMBAHASAN}

\section{Penurunan Berat Telur}

Rataan penurunan bobot pada perendaman telur dalam gel lidah buaya pada Tabel 1 memiliki nilai terendah pada kelompok perendaman telur selama 40 menit $(3,10 \%)$, diikuti kelompok 20 menit $(3,18 \%), 30$ menit $(3,24 \%), 10$ menit $(3,36 \%)$, dan tanpa perendaman $(3,70 \%)$.

Hasil analisis varians menunjukkan bahwa tidak terdapat perbedaan yang nyata $(\mathrm{P}<0.05)$ terhadap nilai bobot telur.

Ini sejalan dengan penelitian Purwaningsih et al. (2016), yang juga tidak mendapati perbedaan yang nyata pada berat telur ayam ras saat penyimpanan setelah pengolesan Aloe vera.

Pada Tabel 1 menunjukkan bahwa penurunan berat telur dengan lama perendaman selama 20 menit dan 40 menit memiliki hasil yang terbaik. Ini menunjukkan bahwa gel lidah buaya mampu mengendap dan menutupi poripori kulit telur untuk memperlambat penguapan. Menurut Siregar (2012) bahwa menurunnya berat telur disebabkan karena terjadinya pelepasan gas seperti $\mathrm{CO}_{2}, \mathrm{NH}_{2}$, $\mathrm{N}_{2}$ dan $\mathrm{H}_{2} \mathrm{~S}$ dan penguapan air serta 
Tabel 1. Rataan Persentase Penurunan Berat Telur (\%)

\begin{tabular}{ccccccc}
\hline & \multicolumn{5}{c}{ Lama Penyimpanan (hari) } & \\
\cline { 2 - 6 } $\begin{array}{l}\text { Lama } \\
\begin{array}{l}\text { Perendama } \\
\mathrm{n} \text { (menit) }\end{array}\end{array}$ & 0 & 10 & 20 & 30 & 40 & Rataan \\
\hline 0 & 0,00 & $2,10 \pm 0,49$ & $3,65 \pm 0,23$ & $5,47 \pm 0,34$ & $7,29 \pm 0,45$ & $3,70 \pm 2,85$ \\
10 & 0,00 & $1,98 \pm 0,24$ & $3,36 \pm 0,22$ & $4,90 \pm 0,09$ & $6,49 \pm 0,46$ & $3,36 \pm 2,52$ \\
20 & 0,00 & $1,67 \pm 0,16$ & $3,34 \pm 0,27$ & $4,67 \pm 0,18$ & $6,17 \pm 0,29$ & $3,18 \pm 2,44$ \\
30 & 0,00 & $1,81 \pm 1,00$ & $3,40 \pm 0,63$ & $4,76 \pm 0,70$ & $6,24 \pm 0,35$ & $3,24 \pm 2,44$ \\
40 & 0,00 & $1,66 \pm 0,16$ & $3,22 \pm 0,18$ & $4,66 \pm 0,52$ & $5,94 \pm 0,36$ & $3,10 \pm 2,34$ \\
\hline Rata-rata & 0,00 & $1,84 \pm 0,22$ & $3,39 \pm 0,21$ & $4,89 \pm 0,40$ & $6,43 \pm 0,68$ & \\
\hline
\end{tabular}

pelepasan gas tersebut terjadi terus menerus maka berat telur lama kelamaan menjadi turun.

\section{Indeks Putih Telur}

Pengaruh lama perendaman telur ayam ras dalam ekstrak lidah buaya terhadap kualitas indeks putih telur ayam ras dapat dilihat pada Tabel 2.

Rataan indeks putih telur pada perendaman telur dalam gel lidah buaya pada Tabel 2 memiliki nilai tertinggi pada lama perendaman $30(0,130 \mathrm{~mm})$ dan 40 menit $(0,130 \mathrm{~mm})$, diikuti lama perendaman $10(0,128 \mathrm{~mm})$ dan 20 menit $(0,127 \mathrm{~mm})$.

Hasil analisis varians menunjukkan perbedaan yang nyata $(\mathrm{P}<0.05)$ dalam penurunan indeks putih telur setelah perendaman gel Aloe vera. Hal ini sejalan dengan temuan Purwaningsih et al. (2016) yang menemukan perbedaan yang nyata $(\mathrm{P}<0.05)$ dalam penurunan indeks putih telur setelah perendaman gel Aloe vera.
Menurut Koswara

(2009)

menyatakan bahwa telur yang baru mempunyai indeks putih telur antara 0,050-0,174. Menurut Standar Nasional Indonesia, telur dengan mutu kelas II, mempunyai indeks putih telur setidaknya 0,092. Jika dilihat pada Tabel 2, telur tanpa perendaman mampu menjaga kualitas telur hingga 20 hari, sedangkan telur dengan perendaman mempu menjaga kualitas telur hingga 30 hari. Menurut Djaelani et al. (2016) bahwa semakin lama penyimpanan maka tinggi putih telur akan menurun dengan cepat. Putih telur sebagian besar mengandung unsur anorganik natrium dan kalium bikarbonat, saat terjadi penguapan $\mathrm{CO}_{2}$ selama penyimpanan maka putih telur menjadi alkalis yang berakibat $\mathrm{pH}$ putih telur meningkat. Menurut Azizah (2018) menyatakan tinggi putih telur semakin lama disimpan akan semakin turun, demikian juga dengan bobot telur. Indeks putih telur dipengaruhi oleh lama 
Tabel 2. Rataan Indeks Putih Telur (mm)

\begin{tabular}{|c|c|c|c|c|c|c|}
\hline \multirow[b]{2}{*}{$\begin{array}{l}\text { Lama Perendaman } \\
\text { (menit) }\end{array}$} & \multicolumn{5}{|c|}{ Lama Penyimpanan (Hari) } & \multirow[b]{2}{*}{ Rataan } \\
\hline & 0 & 10 & 20 & 30 & 40 & \\
\hline 0 & $0,170 \pm 0,003$ & $0,149 \pm 0,002$ & $0,075 \pm 0,015$ & $0,030 \pm 0,002$ & $0,005 \pm 0,002$ & $0,086 \pm 0,072^{c}$ \\
\hline 10 & $0,172 \pm 0,001$ & $0,166 \pm 0,003$ & $0,143 \pm 0,003$ & $0,110 \pm 0,095$ & $0,050 \pm 0,006$ & $0,128 \pm 0,050^{\mathrm{b}}$ \\
\hline 20 & $0,168 \pm 0,003$ & $0,166 \pm 0,002$ & $0,147 \pm 0,012$ & $0,102 \pm 0,002$ & $0,052 \pm 0,002$ & $0,127 \pm 0,050^{\mathrm{b}}$ \\
\hline 30 & $0,173 \pm 0,002$ & $0,165 \pm 0,004$ & $0,138 \pm 0,006$ & $0,121 \pm 0,006$ & $0,052 \pm 0,008$ & $0,130 \pm 0,048^{b}$ \\
\hline 40 & $0,171 \pm 0,003$ & $0,166 \pm 0,003$ & $0,144 \pm 0,007$ & $0,116 \pm 0,006$ & $0,051 \pm 0,003$ & $0,130 \pm 0,049^{b}$ \\
\hline Rataan & $0,171 \pm 0,001^{\mathrm{a}}$ & $0,162 \pm 0,008^{a}$ & $0,129 \pm 0,032^{b}$ & $0,096 \pm 0,046^{\mathrm{c}}$ & $0,042 \pm 0,024^{\mathrm{d}}$ & \\
\hline
\end{tabular}

Keterangan : superskrip berbeda pada baris dan kolom yang sama menunjukan perbedaan yang nyata $(\mathrm{P}<0,5)$

penyimpanan, peningkatan $\mathrm{pH}$ akibat penguapan $\mathrm{CO} 2$ dan kerusakan serabut ovomucin (Riawan et al., 2017).

\section{Indeks Kuning Telur}

Pengaruh lama perendaman telur ayam ras dalam ekstrak lidah buaya terhadap kualitas indeks kuning telur ayam ras dapat dilihat pada Tabel 3. Rataan Indeks Kuning Telur pada perendaman telur dalam gel memiliki nilai tertinggi pada lama perendaman 10 menit $(0,342$ $\mathrm{mm})$, diikuti lama perendaman $20(0,334$ $\mathrm{mm}), 30$ menit $(0,332 \mathrm{~mm})$, dan 40 menit $(0,332 \mathrm{~mm})$. Hasil analisis varians menunjukan perbedaan yang nyata $(\mathrm{P}<0.05)$ dalam penurunan indeks kuning telur setelah perendaman gel lidah buaya.

Jika mengacu pada Standar Nasional Indonesia (2008) yang menyatakan indeks kuning telur segar berkisar antara 0,33-0,52 $\mathrm{mm}$. Terlihat pada Tabel 3 bahwa telur tanpa perendaman gel hanya dapat bertahan hingga 10 hari, sedangkan telur dengan perendaman gel lidah buaya dapat bertahan hingga 20 hari.

Gel lidah buaya diduga dapat menghambat laju atau proses transfer air dari putih ke kuning telur. Hal ini disebabkan tekanan osmosis kuning telur lebih besar dari pada putih telur, sehinga air dan putih telur berpindah menuju ke kuning telur. Perpindahan air secara terus menerus akan menyebabkan ukuran kuning telur menurun, sehingga kuning menjadi pipih dan kemudian pecah, perpindahan air tergantung pada kekentalan putih telur (Pando et al., 2012).

\section{Haugh unit}

Pengaruh lama perendaman telur ayam ras dalam gel lidah buaya terhadap kualitas haugh unit telur ayam ras dapat dilihat pada Tabel 4. Rataan Haugh Unit pada perendaman telur dalam gel memiliki nilai tertinggi pada lama perendaman 10 menit (60,88), 20 menit $(60,20), 30$ menit $(60,87)$, dan 40 menit $(60,12)$, diikuti tanpa perendaman $(55,27)$. 
Tabel 3. Rataan Indeks Kuning Telur (mm)

\begin{tabular}{|c|c|c|c|c|c|c|}
\hline \multirow[b]{2}{*}{$\begin{array}{l}\text { Lama Perendaman } \\
\text { (menit) }\end{array}$} & \multicolumn{5}{|c|}{ Lama Penyimpanan (Hari) } & \multirow{2}{*}{ Rataan } \\
\hline & 0 & 10 & 20 & 30 & 40 & \\
\hline 0 & $0,453 \pm 0,019$ & $0,337 \pm 0,039$ & $0.213 \pm 0,004$ & $0,090 \pm 0,010$ & $0,010 \pm 0,000$ & $0,220 \pm 0,179^{\mathrm{c}}$ \\
\hline 10 & $0,493 \pm 0,031$ & $0,427 \pm 0,036$ & $0.357 \pm 0,012$ & $0,263 \pm 0,018$ & $0,150 \pm 0,020$ & $0,342 \pm 0,139^{b}$ \\
\hline 20 & $0,490 \pm 0,035$ & $0,430 \pm 0,015$ & $0.370 \pm 0,022$ & $0,250 \pm 0,026$ & $0,133 \pm 0,043$ & $0,334 \pm 0,145^{\mathrm{b}}$ \\
\hline 30 & $0,447 \pm 0,004$ & $0,407 \pm 0,016$ & $0.370 \pm 0,024$ & $0,277 \pm 0,009$ & $0,153 \pm 0,021$ & $0,332 \pm 0,120^{\mathrm{b}}$ \\
\hline 40 & $0,477 \pm 0,022$ & $0,420 \pm 0,010$ & $0.333 \pm 0,035$ & $0,260 \pm 0,039$ & $0,173 \pm 0,018$ & $0,332 \pm 0,124^{\mathrm{b}}$ \\
\hline Rataan & $0,472 \pm 0,012^{\mathrm{a}}$ & $0,408 \pm 0,042^{\mathrm{ab}}$ & $0.329 \pm 0,060^{\mathrm{b}}$ & $0,228 \pm 0,085^{\mathrm{c}}$ & $0,124 \pm 0,082^{\mathrm{d}}$ & \\
\hline
\end{tabular}

Keterangan : superskrip berbeda pada baris dan kolom yang sama menunjukan perbedaan yang nyata $(\mathrm{P}<0,5)$

Hasil analisis varians menunjukkan perbedaan yang nyata $(\mathrm{P}<0.05)$ dalam penurunan Haugh Unit setelah perendaman gel lidah buaya. Temuan ini Sejalan dengan temuan Purwaningsih et al. (2016) yang meneliti perubahan Haugh Unit pada penyimpanan telur setelah pengolesan gel Aloe vera.

Jika mengacu pada Standar Agrikultur Amerika Serikat (2000) yang menyatakan Haugh unit telur segar setidaknya bernilai 51 , maka terlihat pada Tabel 4 bahwa telur tanpa perendaman gel hanya dapat bertahan hingga 20 hari, sedangkan telur dengan perendaman gel lidah buaya dapat bertahan hingga 30 hari. Hal ini menunjukkan semakin lama telur disimpan maka haugh unit akan semakin menurun karena terjadi pengenceran putih telur yang diakibatkan penguapan gas $\mathrm{CO}_{2}$ sehingga $\mathrm{pH}$ naik dan mempercepat pemecahan ovomucin. Menurut Nugroho dan Manyun (2008) menyatakan bahwa pengenceran bagian putih telur disebabkan oleh adanya kerusakan fisikokimia dari serabut ovomucin. Ovomucin merupakan glikoprotein yang berbentuk serabut atau jala-jala yang dapat mengikat cairan telur untuk dibentuk menjadi struktur gel pada putih telur.

Tabel 4. Rataan Haugh Unit Telur

\begin{tabular}{|c|c|c|c|c|c|c|}
\hline \multirow{2}{*}{ Lama Perendaman (menit) } & \multicolumn{5}{|c|}{ Lama Penyimpanan (Hari) } & \multirow[b]{2}{*}{ Rataan } \\
\hline & 0 & 10 & 20 & 30 & 40 & \\
\hline 0 & $72,20 \pm 0,90$ & $64,87 \pm 1,10$ & $51,43 \pm 1,02$ & $47,87 \pm 1,62$ & $43,00 \pm 1,83$ & $55,27 \pm 11,80^{c}$ \\
\hline 10 & $72,80 \pm 0,60$ & $68,83 \pm 0,41$ & $63,60 \pm 2,90$ & $50,67 \pm 1,32$ & $46,50 \pm 1,54$ & $60,88 \pm 11,30^{b}$ \\
\hline 20 & $72,70 \pm 1,01$ & $69,30 \pm 1,32$ & $62,43 \pm 2,52$ & $49,47 \pm 2,14$ & $45,43 \pm 1,95$ & $60,20 \pm 11,84^{b}$ \\
\hline 30 & $73,40 \pm 0,14$ & $70,30 \pm 0,71$ & $63,70 \pm 1,32$ & $51,03 \pm 1,58$ & $45,93 \pm 1,46$ & $60,87 \pm 11,98^{\mathrm{b}}$ \\
\hline 40 & $73,03 \pm 0,31$ & $70,17 \pm 0,53$ & $63,73 \pm 2,98$ & $49,80 \pm 1,84$ & $43,87 \pm 3,36$ & $60,12 \pm 12,76^{\mathrm{b}}$ \\
\hline Rataan & $72,83 \pm 0,42^{\mathrm{a}}$ & $68,69 \pm 2,65^{\mathrm{a}}$ & $61,31 \pm 6,15^{b}$ & $50,37 \pm 1,40^{c}$ & $45,15 \pm 1,25^{\mathrm{d}}$ & \\
\hline
\end{tabular}

Keterangan : superskrip berbeda pada baris dan kolom yang sama menunjukan perbedaan yang nyata $(\mathrm{P}<0,5)$ 


\section{KESIMPULAN}

Perendaman telur ayam ras dalam gel lidah buaya dapat memperpanjang masa simpan hingga 30 hari.

\section{DAFTAR PUSTAKA}

Azizah, N. M., A. Djaelani dan S. M. Mardiati (2018). Kandungan protein, indeksputih telur (IPT) dan hough unit (HU) telur itik setelah perendaman dengan larutan daun jambu biji (Psidium guajava) yang disimpan pada suhu 27C. Buletin Anatomi dan Fisiologi 3(1) :46-55.

Badan Standarisasi Nasional. 2008. Telur Ayam Konsumsi. SNI 01-39262008. BSN, Jakarta. Bell, D. \& Weaver. 2002. Commercial Chicken Meat and Egg. Kluwer Academic Publishers, New York.

Djaelani, A.M. 2016. Ukuran rongga udara, $\mathrm{pH}$ telur dan diameter putih telur, ayam ras (Gallus L.) setelah pencelupan dalam larutan rumput laut dan disimpanan beberapa waktu. Buletin Anatomi dan Fisiologi. Jurnal 1(1): 19-23.

Jatnika, A dan Saptoningsih. 2009. Meraup Laba dari Lidah Buaya. Agromedia Pustaka. Jakarta.

Koswara, S. 2009. Teknologi Pengolahan Telur (Teori dan Praktek). eBookPangan.com

Muchtadi D, 2009. Prinsip Teknologi Pangan: Sumber Protein. Penerbit Alfabeta, Bandung.
Nugroho dan Manyun, I.G.T. 2008. Beternak Burung Puyuh. Eka Offset. Semarang.

Pando, S., L. Thomsen, A. Balen. 2012. Physical transport properties of marine microplastic polution. Biogeosci. 9: 18755-18798

Purwaningsih, D., M.A. Djaelani, dan T.R. Saraswati. 2016. Kualitas telur ayam ras setelah pemberian olesan Lidah Buaya (Aloe vera) dan lama penyimpanan waktu yang berbeda. Buletin Anatomi dan Fisiologi 24 (1): 13-20.

Riawan. 2017, Pengaruh Perendaman Telur Menggunakan Larutan Daun Kelor Terhadap Kualitas Internal Telur Ayam Ras. Skripsi. Universitas Lampung. Lampung.

Siregar, F.R., A. Hintono, dan S. Mulyani. 2012. Perubahan sifat fungsional telur ayam ras pasca pasteorisasi. Animal Agriculture Jurnal 1 (1): 521-528

Steel, R. G dan J. H. Torrie. 1991. Prinsip dan Prosedur Statistika Suatu Pendekatan Biometrik. Edisi 2 cetakan 2. Alihbahasa Bambang Sumantri. PT.Gramedia Pustaka Utama, Jakarta.

Sudaryani. 2003. Kualitas Telur. Penebar Swadaya. Jakarta.

Sudaryani (2000). Pembibitan ayam ras. Penebar Swadaya. Jakarta.

Surjushe, A., R. Vasani, D.G. Saple. 2008. Aloe vera: A Short Review. Indian Journal of Dermatology 53(4): 163-166.

United States Department of Agriculture. 2000. USDA. United States Standards, Grades, and Weight 
Classes for Shell Eggs. AMS 56. Washington, DC.

Valverde, J. M., D. Valero, D. MartínezRomero, F. Guillén, S. Castillo, and M. A. Serrano 2005. Novel Edible Coating Based on Aloe vera Gel to Maintain Table Grape Quality and Safety. Journal of Agricultural and Food Chemistry. Vol.53, pp 7807-7813. 